\title{
The Delaying of Inherited Wealth Distribution and Its Impact: A Case Study of Family Fair in Medan City
}

\section{| Fathul Djannah ${ }^{1}$ | Muhammad Rizal ${ }^{2}$ |}

${ }^{1}$ Universitas Pembangunan

Panca Budi Medan, Indonesia

${ }^{2}$ Universitas Islam Negeri Sumatera Utara

${ }^{1}$ djannahf@gmail.com

2mrizal0923@gmail.com

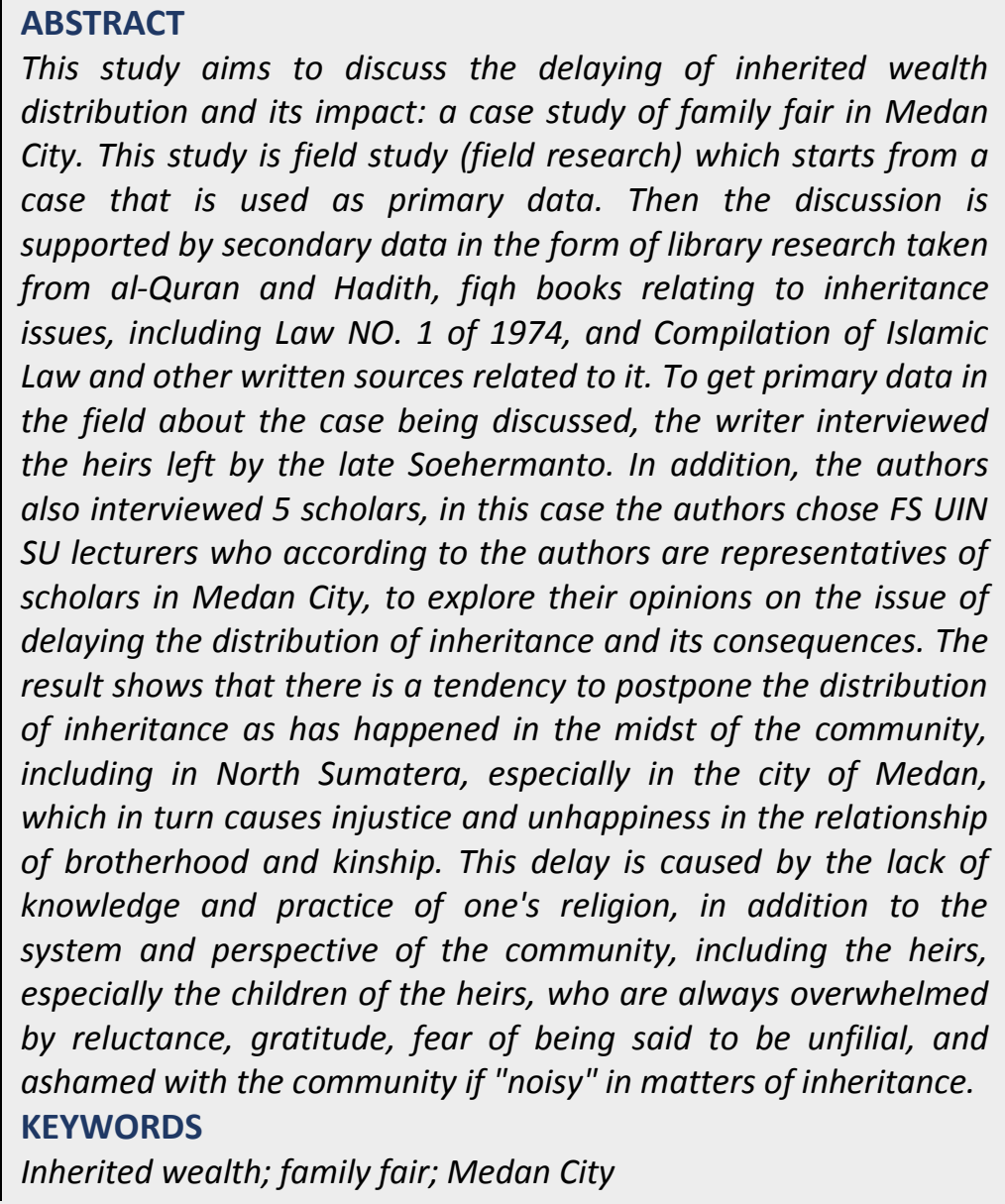
distribution and its impact: a case study of family fair in Medan City. This study is field study (field research) which starts from a case that is used as primary data. Then the discussion is supported by secondary data in the form of library research taken from al-Quran and Hadith, figh books relating to inheritance issues, including Law NO. 1 of 1974, and Compilation of Islamic Law and other written sources related to it. To get primary data in the field about the case being discussed, the writer interviewed the heirs left by the late Soehermanto. In addition, the authors also interviewed 5 scholars, in this case the authors chose FS UIN SU lecturers who according to the authors are representatives of scholars in Medan City, to explore their opinions on the issue of delaying the distribution of inheritance and its consequences. The result shows that there is a tendency to postpone the distribution of inheritance as has happened in the midst of the community, including in North Sumatera, especially in the city of Medan, which in turn causes injustice and unhappiness in the relationship of brotherhood and kinship. This delay is caused by the lack of knowledge and practice of one's religion, in addition to the system and perspective of the community, including the heirs, especially the children of the heirs, who are always overwhelmed by reluctance, gratitude, fear of being said to be unfilial, and ashamed with the community if "noisy" in matters of inheritance. KEYWORDS

Inherited wealth; family fair; Medan City

\section{INTRODUCTION}

Apart from the various terms used by the scholars, the issue of inheritance, the transfer of property from someone who has died (waristun) to the living (ahlu al-warist), in the provisions of Islamic law occupies a very important position so that it becomes a special concern among the fuqoha.

The provision of the distribution of inheritance has been explained in the Quran in detail about the law and parts obtained by each heir, as seen in surah an-Nisa 'from verse 7 to verse 14 , verse 33, and 176 that speak about the male and female part in general, the male and female part, the father and mother part, the wife or husband section to the part of a person, and likewise surah al-Anfal verse 75 which talks about the ulul arham section.

Besides the Quran, the traditions of the prophet also talk a lot about inheritance, which is also a reinforcement of the commands and provisions of the Quran, among others, which means: "Give the faraid (predetermined portions) to those who are entitled and the rest give it to men of male descendants ".

For these reasons, there is actually no real reason not to immediately distribute inheritance to the heirs who are entitled to receive it. Although the situation and conditions, 
such as not being separated between inheritance with assets for other portions, is not yet possible to divide it directly, but at least every heir already knows which part and how much the portion of the inheritance he will get later.

Actually, Islam wants the inheritance to be immediately divided according to the existing faraid provisions in order to create a calm relationship and feeling in the circle of brotherhood both in the form of nuclear family and extended family. But in the reality of social life (das sollen), what is desired by the Islamic inheritance law, including the provisions of the part and the necessity to hasten the distribution of inheritance, sometimes always does not match as it should (das sein). This phenomenon is inseparable from the understanding of religion, systems and culture that develops in the midst of Indonesian society, especially in North Sumatera, which always puts respect, reluctance, shame, Pakewuh attitude, and so forth, which in turn makes the heirs feel reluctant or ashamed to claim inheritance that is still controlled by one of the heirs who is still alive, such as the mother or father of the heir.

Because death is considered something very extraordinary and very sacred, then what is caused by the death, especially regarding inheritance rights to inheritance, becomes something taboo to be questioned or questioned, especially if one of the heirs is still alive.

On one hand, this reluctance to challenge the rights and distribution of inheritance can be seen as an effort to support the continuation of the family left by the father or mother, but on the other hand it can cause new problems, for example if the mother or father remarries while the inheritance has not been faraidkan. Similarly, if the mother who died while the father remarried in the condition of inheritance of the wife (mother) has not been distributed to her children, and even worse if before the death of the mother, the father already has a second wife, and so on.

In a situation like this, the problem will become more complicated because the inheritance left behind is no longer pure as it was originally, but has also experienced development and mixing in various forms of asset development, business ventures and others mixed with joint assets from the joint property of the wife first and with the share of property with the second wife.

Cases like this are not uncommon in the community, which in turn sometimes inheritance does not directly bring benefits, prosperity and happiness to the heirs, but must first go through fights or fights and even killings that destroy blood relations. and marriage in the form of a nuclear family and extended family.

As one example of the above phenomenon he is a case that occurred in Medan City which is chronologically and systematically the results of his research the authors convey in the form of papers, as one of the obligations in fulfilling the duties of Islamic Family Law courses in Indonesia, guided by Prof. Pagar Hasibuan, M. Ag, with the title "The Delaying of Inherited Wealth Distribution and Its Impact: A Case Study of Family Fair in Medan City"

\section{RESEARCH METHODS}

This study is field study (field research) which starts from a case that is used as primary data. Then the discussion is supported by secondary data in the form of library research taken from al-Quran and Hadith, fiqh books relating to inheritance issues, including Law NO. 1 of 1974, and Compilation of Islamic Law and other written sources related to it.

To get primary data in the field about the case being discussed, the writer interviewed the heirs left by the late Soehermanto. In addition, the authors also interviewed 5 scholars, in this case the authors chose FS UIN SU lecturers who according to the authors are 
representatives of scholars in Medan City, to explore their opinions on the issue of delaying the distribution of inheritance and its consequences.

While in analyzing data, the writer uses descriptive-qualitative analysis with the ushul fiqh approach based on maqashid as-syar'iyah. Descriptive-qualitative analysis is used to find out in detail about the case that occurred and the impact it raises. While the ushul figh approach, the writer uses to see and know in depth the meaning and wisdom of accelerating the distribution of inheritance as an effort to find the avoid misunderstanding.

The formulation of the problem put forward is:

a. What is the understanding and practice of the Soehermanto family's religion?

b. What factors have caused the delay in the distribution of Soehermanto's family inheritance wealth?

c. What is the ulama's view of the delay in the distribution of inheritance wealth and what impact does it have?

d. This research is an academic input for the study of inheritance laws, especially those relating to the problem of delaying the distribution of inheritance that always arises in the midst of society.

\section{RESULT AND DISCUSSION}

\section{Inherited Wealth Distribution in the Frame of Maqashid Al-Hukm Al-Islam Al- Indonesiyyi}

It is interesting to note what Fazlur Rahman has written if new powerful forces, whether in the social, economic, political, cultural or moral fields, occur in a national society so it is certain that their fate will depend on how strong they are capable face these new challenges creatively or to what extent they can carry out rejections with the beliefs they maintain frantically, and seek fictional protection from the past. For those who are trapped in the fictional past lives, however beautiful the memories of the past are, unable to face the present reality bravely, however bitter this reality is, they will turn into fossils; and an unchangeable sunnatullah is that fossils cannot sustain their lives for quite a long time.

What Rahman said above is a historical fact that cannot be denied that a change, big or small, will definitely have an impact on other changes; because life is indeed change, and death is stagnation, including the stagnation of "social reason" in various dimensions, such as the political dimension that can make changes radically, including changes in law.

In the case of Indonesia it is clearly seen that Indonesia's independence in 1945 not only brought changes in the flow of political dynamics, but also brought a spirit of broader change, including in the issue of Islamic family civil law (ahwalu as-syakhsiyah) and the regulation and institutionalization of Islamic based institutions established by the government.

One of the most important developments to note is the issuance of regulations on the institutionalization of the Religious Courts institution and the transfer of the authority of the Religious Courts from the Minister of Justice to the Minister of Religion in the 1950s. In addition, through this long, dynamic and possibly exhausting process of evolution, the need and demand for reform of Islamic law has been and continues to be voiced for at least the past three decades.

The first outcome of this reform process was born in 1974 when the Indonesian government passed Law no. 1 dealing with Marriage Law which substantially accommodates the needs and desires of the Islamic legal community in Indonesia. This strong current of change also occurs in various parts of the Islamic State or predominantly Muslim, such as Morocco, Sudan, Egypt, Malaysia, and others. 
The need for sociological changes in law is closely related to the extent to which the law can meet and answer the problems that arise in the midst of society, borrow economic terms, what I call the theory of demand and supply of law (people's needs for law and answers law).

In connection with the needs and legal answers will certainly be different for each group of people, nation and state in accordance with the character and social typology adopted and which develop naturally and fundamentally. Therefore it is imperative to undertake various efforts to reinterpret, reform, reconstruct, re-actualize legal concepts, etc. to be able to be in touch with the needs and demands of the community both culturally and constitutionally, including

An interesting thing to look at further is the background why KHI is present in the midst of the struggle for family jurisprudence law in Indonesia. The one reason is because of the uncertainty and confusion in the decisions of the Religious Courts on issues of authority that were triggered by the absence of a national basis for judges in making decisions. The judges make reference to the decision based on the opinions of the scholars in the books of fiqh, which always differ from one another in the same matter. Therefore, different decisions often occur between one Religious Court and other Religious Courts on the same issue.

The efforts of the government to produce Indonesian Islamic inheritance law which are Indonesian in nature should be appreciated academically, but the KHI itself has not been completed in the discussion of its articles because there are still many uncovered portions as mentioned by the Quran and Hadith, for example on the issue of dzawi al furudh, 'ashabah and dzawi al arham clearly. Besides that, KHI also does not seem to be able to escape significantly from the classical fiqh opinion that smells of arabism.

Of the 43 articles of inheritance in KHI, (articles 171 to 214), only one article can be said to truly be the Islamic inheritance law of Indonesia, namely article 185 concerning successor heirs, according to Yahya Harahap that this provision is a new and constitutes a breakthrough in the abuse of grandchildren's rights over the inheritance of the father, if the father dies earlier than the grandfather, whose sound is complete the article is as follows: point 1 . The heirs who died earlier than the heir then his position can be replaced by his child, except those who mentioned in article 173, point 2 . The portion for substitute heirs must not exceed that of the heirs equal to those replaced.

The impact of this delay also makes people illegally eat the property of others, cause a dispute in the middle of the family between the heirs and can be a tilted issue to the heir's family in the midst of social life.

\section{Case Study and Solving}

\section{Chronological}

First Marriage

A man, named Adil Soehermanto, married a woman named Tias Ningsih Sartika on February 10, 1970, then had a child, namely:

a. Chandra Soehermanto, ST (L) was born in 1971, married in 1996. Then died in 2007, and left a wife with 2 children (a son and a daugther).

b. Dedy Soehermanto, SE (L) was born in 1973.

c. Elma Soehermanto, SH (P) was born in 1975.

d. Ferdiyansyah Soehermanto, SE., MBA (L) was born in 1977.

e. Glady Soehermanto, S. Sos (P) was born in 1980. 


\section{Second Marriage}

On June 6, 2000, Adil Soehermanto remarried a woman, a widow with a child, named Delimawati Dalimunte, SE. Ak From this marriage was born a boy named Hendrito Soehermanto.

Dead wife and child

On September 19, 2002, Tias Ningsih Sartika (Adil Soehermanto's first wife) died of heart disease, and in 2007 Chandra Soehermanto (Adil Soehermanto's first child) died of a collision.

Died husband

On September 3, 2010 Adil Soehermanto died of diabetes, leaving 6 heirs, namely: 3 boys and 1 daughter from the first wife, a wife (second wife) with 1 son-man

\section{Legacy}

a. Cash funds of 1.2 billion Rupiah

b. Land of 800 meters in the center of the city, with houses purchased in 1985 .

c. Kebon $100 \mathrm{H}$ in Riau Province, bought in 1996.

d. BMW Sedan in 19901 unit (purchased in 1990).

e. Mercedes Bens Sedan in 20001 unit (purchased in 2000).

f. Alphard Cars in 20091 unit (purchased in 2009).

g. The company in the form of a PT engaged in the export of coffee and other agricultural products since (established in 1980).

Relax Heritage

a. Cash funds of Rp. 1,200,000,000

b. Land and buildings (houses) Rp. 1,000,000,000

c. Palm oil Rp. 2,000,000,000

d. 1990 BMW cars Rp. 40,000,000

e. Mersedes Bens car in 2000 Rp. 95,000,000

f. Alphard Cars in 2009 Rp. 1,000,000,000

g. Company Assets Rp. 100,000,000

h. Total Rp. 5,435,000,000

(Five Billion Four Hundred Thirty Five Million Rupiah)

Dispute

As a father, Adil Soehermanto is fully responsible for guiding and providing education to his children, so that all of his children are included in the category of successful families. Because they have succeeded, besides feeling reluctant to parents, in this case the father, they are not too concerned with the inheritance left by their mother. While the father (Adil Soehermanto) also did not give his children's rights as heirs. Then he marries and continues to manage all the available assets, including those belonging to (left by) his first wife. The late Soehermanto left no will and did not share the rights of his children until his death.

Since the death of Soehermanto, a complicated problem has arisen. On the one hand, Soehermanto's children from the first wife who knew of their rights, including the rights of their brother (brother) who died earlier than their mother, were divided according to faraid law, while, on the other hand, the second wife maintain and try to control all existing assets. 
This problem they had actually discussed with a cleric named Drs. H. Abdul Majid, who happened to be a friend of the writer, and was huddled with the late wife of the late Adil Soehermanto. According to Abdul Majid, what made this case complicated was the participation of the second brothers and sisters to support the possession of the property so that a physical fight between the heirs and one of the second wives ended up in the hospital, and was eventually reconciled by the authorities.

\section{Problem Solving}

Basically this case can be seen from two legal perspectives, namely faraid law and KHI that apply in Indonesia. This is important because there are several different points of view and provisions, including the position of property, the position of the grandchildren of the child who died earlier than the heir (father or mother). Regarding the position of assets, in faraid law there is no known position of shared assets while in KHI there are provisions regarding divorce payout. Besides that, the position of the child who died earlier than the father or mother is not included in the group of heirs according to faraid law, but the grandchildren who are left behind have a mandatory will. Whereas according to KHI the position of divorce payout has a strong legal position, and the position of grandchildren occupies the position of his father, and the will is obligatory only for adopted children or stepfather.

In connection with the distribution of the inheritance of the late Soehermanto family, there are several steps that must be taken, namely: the first step that must be taken is to collect all assets owned by the late Soehermanto family in the form of cash, land and house, oil palm, car and asset assets in the form company. Then all assets must be classified in advance of the purchase period between the first marriage period and the second marriage period. After that, the assets are separated before and after the first wife dies, for example how much cash is stored until the death of the first wife, when to buy land / houses, garden, cars and when the establishment of the company, and the number of assets that develop such as garden and company.

With regard to developing assets, professional calculations are needed, if necessary using the services of consultants or notaries, so that the distribution of the results of the development of assets can be calculated appropriately. This is important, considering that the asset was purchased when the first wife is still alive, then the second wife and the child of the second wife are only entitled to get their share of the results of the development of the asset, not the asset itself ('ain al-mal), because all assets that are purchased during the first wife only returned to the children of the first wife.

The next step is to separate all inheritance while the first wife is still alive and inheritance with the second wife. After that, then other compulsory matters are settled, such as paying off debts, wills, if any, and giving alms to relatives and poor people, whether present or not in the moment of the distribution of inheritance, as stated in Surah an-Nisa'ayat 8 which means: "And if there were relatives, orphans and poor people present during the distribution, then give them away from that treasure (modestly) and say to them good words".

The next step is to determine which heirs are entitled to inheritance. Because the deceased has two wives who each have children, the heirs can be divided in two, first the heirs with the first wife and second heirs with the second wife.

The composition of the heirs of the first wife (in a state of not having a father and mother) are: Adil Soehermanto (husband), Chandra Soehermanto, Dedy Soehermanto and Ferdiansyah Soehermanto, Elma Soehermanto and Glady Soehermanto. While the heirs of the late Soehermanto (also in a state of not having a father and mother) after death the first 
wife was: Delimawati Dalimunte (second wife), Chandra Soehermanto (successor), Dedy Soehermanto, Ferdiansyah Soehermanto, Elma Soehermanto, Glady Soehermanto (children), Dedy Soehermanto, Ferdiansyah Soehermanto, Elma Soehermanto, Glady Soehermanto (children) from the first wife), and Hendrito Soehermanto (son of the second wife).

Then determine the percentage of each heir as follows:

a. For the heirs of the late Tias Ningsih Sartika: Adil Soehermanto (husband) gets 1/4 (25\%) of all assets, the remaining 3/4 or $75 \%$ becomes ashabah for all their children with the following details (2: 1): Chandra Soehermanto, Dedy Soehermanto and Ferdiansyah Soehermanto each received $18.75 \%$. While Elma Soehermanto and Glady Soehermanto each received 9.375\%.

b. For the section of the heirs of the late Soehermanto:

In addition to getting his share of the joint property (Gono Gini assets), Delimawati Dalimunte (wife) gets $1 / 8(12.5 \%)$ of all her husband's inheritance, the remaining $7 / 8$ or $82.5 \%$ becomes an heir for all children those with the following details (2: 1): Chandra Soehermanto (successor to inheritance), Dedy Soehermanto, Ferdiansyah Soehermanto (child of first wife), and Hendrito Soehermanto (child of second wife) each received $16.5 \%$. While Elma Soehermanto and Glady Soehermanto (children of the first wife) each received $8.25 \%$.

\section{The Case Analysis}

The case of delaying the distribution of inheritance among the people of North Sumatera, including in Medan City, is actually a case that often occurs. This is inseparable from the social system and structure as well as the existing religious understanding in which the community, on the one hand, is very religious in religion, especially in the form of worship of mahdah, but on the other hand seems loose when religious issues come into contact with customs and habits, including the community's habit of delaying division of inheritance.

However, the case under discussion has a very interesting plot and is rare in ordinary people, especially those living in rural areas. Imagine, besides the late Adil Soehermanto, a hard worker, caring for his family, and rich, he is also a polygamous husband. Likewise their children are highly educated, insightful, living well and living in the Metropolitan City.

If explored further this case, then there are at least 3 factors causing the delay in the distribution of inheritance by the family of the late Soehermanto family resulting in a fight among the heirs, namely:

a. Religious factors

After the writer traced the track record of the late Soehermanto, the author concluded that the alm included a lack of religious knowledge and practice. As one of the concrete evidence is that until the end of his life, the late had not performed the pilgrimage. Likewise, the information that the author found from the heirs, that the late had never endowed a portion of his property for religious purposes, such as building a mosque or madrasa. However, in the social life of the deceased, including people who are quite generous, this is evidenced that the alma always makes humanitarian contributions through social institutions which the alm are active in, such as the North Sumatera Lions Club.

From some of the information exposure, the authors conclude that religious understanding is different from the social spirit of humanity. Because of the minimization of understanding and religious practice of the deceased being the cause of the delay in the distribution of the inheritance of his first wife to the children he 
left behind, even when the deceased entered his old age, the deceased did not give any will to his children, and even the deceased did not realize that his second wife would become triggers of family problems, in this case the problem of inheritance.

b. Outsider Factor (Polygamy)

Although Islam justifies a man to polygamy, with quite difficult requirements, such as being fair, but the practice of polygamy for the people of North Sumatera, including Medan City, is something that has long been considered inclined, and has been widely opposed by the community, especially since the feminism movement began to surge in Medan in the 1980s.

One other thing that becomes problematic is that when the practice of polygamy is not recorded according to statutory regulations, the marriage is legally considered to be non-existent and has no legal power, and if the husband dies, the inheritance rights of the wife and children are left as experts the inheritance is gone.

c. Attitude of Heirs

The delay in the distribution of inheritance is also related to the attitudes and perspective of the heirs, as happened in the late Adil Soehermanto's family. The heirs of the late Soehermanto felt that they were reluctant and afraid to offend their parents if they asked for inheritance, even though they knew that they had the right to do so. Besides that, they also feel that the services of parents have provided so much education that they are all highly educated and living well. For the sake of maintaining family relationships, and also protecting the good name of the family, they never questioned the deceased until finally the deceased forgot and fell asleep in the crinkle of wealth that is always tempting.

\section{The Inherited Wealth Distribution}

Drs. H. Amin Husein Nasution, MA believes that inheritance must be distributed immediately to the heirs who are entitled to get it. He reasoned that with the words "Nashiban Mafrudha" Allah reminded that the heirs already had the right determined by their share of the inheritance left behind. For this reason, there must be a step to expedite the granting of these rights, and there must be no attempt to delay the heirs to get their rights as soon as possible, because this is more beneficial to the heirs. Because not infrequently fights that result in the killing of heirs.

Meanwhile, Dr. H. Muhammad Jamil, MA stated that the issue of inheritance is a package with the implementation of fardhu kifayah, payment of debts and the implementation of washiyat which must be carried out immediately or fulfilled, as stated in surah an-Nisa 'verse 12. Muhamad Jamil added that paragraph 13 and 14 surah an-Nisa 'states that being sinful, a miracle, if this package, including the distribution of inheritance, is not immediately implemented.

Dr. Amar Adly, Lc., MA, stated that although there are no verses or traditions that order to hasten the distribution of inheritance, the inheritance must be distributed immediately because the inheritance, in addition to helping increase the economic heirs, in order to ward off fights and hostility and avoid mixing of property wife and husband, which they also inherit from each other. If you are forced to slow down, then don't let other heirs die before their distribution.

a. The Factors Cause for The Delaying of Inherited Wealth Distribution

Moving on from the results of the author's interview with the heirs and coupled with some opinions from the scholars in Medan about the connection with why 
delaying inheritance often occurs in the midst of community life, there are at least several reasons, namely:

- Minimal religious knowledge and practice including regarding inheritance law.

- The heirs are far from qurani generation (ulama).

- Factors are reluctant to parents, fear of disobedience.

- The heirs who want to master the reasons as the child who takes care of most heirs.

- Polygamy.

- The existence of an heir's debt, and

- Selfish heirs who want to control inheritance.

b. Impact of the Delaying of Inherited Wealth Distribution

The delay in inherited wealth distribution that often occurs does not always run linear with the reality of people's lives longing for prosperity, justice and peace in the community. But on the contrary it causes various problems that it causes, among others:

- There is a fight or fight between the heirs.

- The benefits of inheritance cannot be maximally developed by each heir in accordance with their rights.

- Appears selfish among children, especially the eldest or, who feel the most meritorious with the late so that the exclusion of others.

- The breakdown of relationship between siblings because they prioritize wealth over brotherhood.

- The occurrence of mixing assets that should be the right of each heir.

- There is a high possibility of the activity of consuming orphans' property in a false way.

- The appearance of a bad image among the people towards the family of the testator.

- Although it does not reach the haram, but the delay will cause a very negative effect on family and community life.

c. Immediate Distribution of Inheritance (principle of harmony in inheritance)

One of the core teachings of Islam is the realization of justice and peace in the order of family, community, nation and state life. Therefore, Islam emphasizes giving rights, and demanding obligations, someone in accordance with their portion, and Islam does not teach to hold or hide one's rights, including in the case of inheritance rights in the form of property or other legal rights, like royalty. Instead, Islam stresses the immediate distribution of inheritance rights, so that they can be controlled and used by the heirs in the service of Allah and provide the best for humanity, including developing the inheritance received.

Immediate distribution of inheritance that is actually desired by Islam at least can be based on three legal grounds, namely:

- Normative foundation

As the main reference for inheritance law, the Koran actually only talks about the inheritance's right to the inheritance's inheritance, and how much or the portion of each is obtained by the heirs, as stated in surah an-Nisa 'starting at verse 7 to verse 14, verse 33, and 176. Al-Quran statement about the rights and portions of each heir is very important considering that the issue of property is a problem that is very sensitive and can cause disharmony, especially among heirs. Therefore, perhaps the Koran deliberately determined it in detail, and 
therefore also the commentators and fuqoha stated that the inheritance verses are included in the verses of the qat'iyut who did not have any interpretation except to follow what has been determined zhahir and clear.

In line with the Koran, the traditions of inheritance also reinforce what has been affirmed by the verse, besides that in the Hadith there is a direct order to give inheritance to the rightful, as in the hadith which reads "Give faraid (the parts that have been determined) it is to those who are entitled and the rest give it to men of male descendants ".

Regardless whether this hadith is understood as something very patrine, the Prophet has ordered that the inheritance must be divided among the rightful heirs. Then the problem is what if the distribution of inheritance is not carried out, or should be distributed immediately and when the right time to divide the inheritance is not the attention of the Koran and the hadith explicitly. However, if only further attention is given to the meaning of muwafaqoh and the purpose of the benefit of the verse, and its relation to the issue of giving or prohibiting restraint, including seizing and consuming the rights of others, for example eating the property of orphans, then it can be said that the distribution of inheritance must be distributed immediately.

With regard to the fear of prohibition on consuming the rights of others, such as the inheritor's debt that must be paid first before the distribution of inheritance is clearly seen in Surah an-Nisa verses 11 and 12 it is stated repeatedly that the inheritance is distributed with the condition "after being given the testator's will and after paying the debt heir". While other general verses forbid many to eat other people's property in a way as in sura al-Baqarah 188 and an-Nisa verse 29.

- Ethical Basis

One of the ethical foundations of brotherhood in peace is related to the delivery of the mandate, namely giving or conveying what is rightfully a person's rights in material and immaterial form. That is, inappropriate and not virtuous when someone tries to hold or hide what should be given. In the terminology given by Ahmad Musthafa al-Maraghi the trust is something that must be maintained and maintained so that it is given to those who are entitled to have it. Al-Margahi further reviews the mandate into three forms, namely: first: the task that must be maintained and carried out by humans against God in the form of carrying out all the commands and leaving all His prohibitions. Second: maintain or give someone's property to the owner of the right, such as returning the deposit to the owner, and giving inheritance to the heirs who have the right to own it. Third: trust in yourself, such as doing something that is best and beneficial for him, meaning not doing something that endangers him, and something that can make others dangerous for it.

Thus, delaying the distribution of inheritance by a person is a violation of the mandate both in the personal-social dimension of humanity and in the divine dimension, and the violation of the mandate is the destruction of the joints of family life, community, nation, state and religion which in turn leads to destruction and kemudharatan.

- Sociological foundation

When viewed from the perspective of social life, the immediate distribution of inheritance is something that should be done for the following reasons: 
First; to avoid conflicts between existing heirs. This is because maintaining family kinship is a priority and an obligation that must be carried out by each individual family, while delaying the distribution of inheritance is an act of withholding rights as well as penitentiary rights of heirs.

Second; to overcome the problems of poverty and productivity. The social reality that cannot be avoided is that the lives of each heir are certainly not the same, both in terms of education, social role, and economic capability, some of which belong to a group of heirs who have a well-established life, but not a few also live in poverty.

Third; so that there is no overlap or mixing of inheritance with noninheritance. For example, as mentioned in the case of the late Soehermanto family's inheritance, there has been a mixture of inheritance rights with the development of assets that have accumulated from all existing inheritance assets.

Fourth; for law enforcement. Provisions regarding inheritance that have been established by the Koran are binding for all Muslims regardless of cultural and national background. If Muslims, in this case are heirs, stick to the provisions and spirit of the Koran, and immediately apply the distribution of inheritance, then indirectly Muslims have taught this nation how to become obedient individuals (communities) azaz and law abiding, including in the national and state health contacts.

\section{CONCLUSION}

One of the core teachings of Islam is the realization of justice and peace in the order of family, community, nation and state life. Therefore, Islam emphasizes giving rights, and demanding obligations, someone in accordance with their portion, and Islam does not teach to hold or hide one's rights, including in the case of inheritance rights in the form of property or other legal rights, such as human rights, matters of royalty, and others. On the other hand, in the case of inheritance, Islam emphasizes that it is immediately distributed to the rightful heirs so that they can control and use their assets in order to serve God, and provide the best for humanity, including developing the inheritance they receive.

However, in reality, there is a tendency to postpone the distribution of inheritance as has happened in the midst of the community, including in North Sumatera, especially in the city of Medan, which in turn causes injustice and unhappiness in the relationship of brotherhood and kinship. This delay is caused by the lack of knowledge and practice of one's religion, in addition to the system and perspective of the community, including the heirs, especially the children of the heirs, who are always overwhelmed by reluctance, gratitude, fear of being said to be unfilial, and ashamed with the community if "noisy" in matters of inheritance.

This minimalism of religious knowledge and practice as well as counter-productive attitudes is, in essence, one of the causes of the delay in the distribution of inheritance which always leads to commotion, even fights and broken relationships of brotherhood. For this reason, for the sake of justice and prosperity, it is time for the indictment to hurry up the distribution of inheritance. Allah knows best.

\section{REFERENCES}

Abdurrahman. (1992). Kompilasi Hukum Islam di Indonesia, Jakarta: Akademi Pressindo..al-Mahally, Jalaluddin. 1960. Syarhu Minhaj al-Thalibin, vol. 3, Kairo: Dar al-Ma'rifah, Al-Maraghi, Ahmad Mushthafa. Tafsir Al-Maraghi, Jilid 2, Beirut: Dar al- 
Fikr, tt. an-Nawawy. Syarhu Shahih Muslim, vol. XI, Kairo: Dar Mathba'ah alMisriyyah, 1974.

Harahap, Yahya. (1992). "Informasi Materi KHI, Mempositifkan Abstraksi Hukum Islam" Dalam Mimbar Hukum: Aktualisasi Hukum Islam, No. 5, Jakarta: al-Hikmah

Hazairin. 1982. Hukum Kewarisan Bilateral Menurut Qur'an Dan Hadith, Jakarta:Tintamas

Hooker, M.B. (1999). "The State and Shari'ah in Indonesia 1945-1995”, dalam TimLindsey (ed.), Indonesia: Law and Society, Sydney: Federation Press.

Lev, Daniel S. (1972). Islamic Courts in Indonesia: A Study in the Political Base of Legal Institutions, Berkeley: University of California Press.

Rahman, Fatchur. (1981). Ilmu Waris, Bandung: al-Ma'arif.

Rahman, Fazlur. (1983). Membuka Pintu Ijtihad, pen. Anas mahyuddin, judul dalam bahasa Inggeris-nya, Islamic Methodology in History, Bandung: Pustaka

Rofiq, Ahmad. (2002). Fiqh Mawaris, cet. ke IV, Jakarta: Rajawali Pers

Sazali, Munawir. (1988). Polemik Reaktualisasi Ajaran Islam, Jakarta: Pustaka Panjimas.

Sjarifuddin. Amir. (2004). Hukum Kewarisan Islam, Jakarta: Kencana Prenada Media

Subekti. 1977. Pokok-Pokok Hukum Perdata, Jakarta: Intermasa

Sunny, Ismail. (1991). "Kedudukan Hukum Islam dalam Sistem Ketatanegaraan Indonesia" dalam Rachmat Djatnika, dkk., Hukum Islam di Indonesia: Perkembangan dan Pembentukan, Bandung: Remaja Rosdakarya

Sya'rawi. (2005). Muhammad Mutawlli, Tafsir Sya'rawi, Tim Penerjemah Safir al-Azhar, vol. 2, Medan: Duta Azhar

Syariduddin, Amir. (2004). Hukum Kewarisan Islam, Jakarta: Prenada Media 